\title{
CAPILLARY PERMEABILITY IN RELATION TO ACUTE ANOXIA AND TO VENOUS OXYGEN SATURATION ${ }^{1}$
}

\author{
By J. HENRY, J. GOODMAN AND J. MEEHAN with the technical assistance of \\ R. FRANKEL \\ (From the Departments of Physiology and Aviation Medicine, University of Southern \\ California, Los Angeles)
}

(Received for publication June 2, 1947)

\section{INTRODUCTION}

It has often been assumed that moderate degrees of hypoxia render the capillaries abnormally permeable to fluid and protein. During the course of work concerned with methods of insuring pilot survival at altitudes above $45,000 \mathrm{ft}$., it became desirable to know the degree and duration of anoxic anoxia that could be tolerated before permeability changes of the capillary bed occurred. The studies of Landis (1) have demonstrated that complete ischemic anoxia of 3 minutes' duration will cause temporary damage to the capillaries of the frog's mesentery and result in abnormal permeability to fluid and protein. Pochin (2) working with the rabbit's ear has found that complete occlusion of the circulation for 2 hours will lead to demonstrable edema following reestablishment of the circulation. He also showed that 16 to 18 hours of occlusion resulted in edema fluid containing approximately 5 grams per cent of protein. Calvin (3) has found that during the terminal stages of fatal asphyxia there is evidence of a marked loss of protein and of the proteinattached dye $\mathrm{T} 1824$ from the capillary bed.

These experiments involved very intense anoxia and on turning to work done under less severe conditions the results are seen to be less conclusive. Thus Calvin (3) and also Hopps and Lewis (4) found no change in the rate of filtration of plasma protein and of the dye T 1824 in the course of severe but non-fatal anoxia. On the other hand Maurer (5) and Warren and Drinker (6) have shown that, in the dog, the flow of cervical and lung lymph increases during severe but non-fatal anoxic anoxia. However

1 This work was supported in part by the AAF Aero Medical Laboratory, Air Materiel Command, Wright Field. the percentage of protein in this lymph decreases with the increased flow and the results do not unequivocally demonstrate an increase in capillary permeability as a result of the acute anoxia. $\mathrm{Ob}$ servations concerning the influence of anoxia have been made in humans. McMichael and Morris (7) have used nitrogen-oxygen gas mixtures of an oxygen percentage ( 9.5 per cent) that would induce approximately 65 per cent arterial hemoglobin saturation. They found no increase in the rate of swelling of the congested arm. Their results suggested that the permeability of the arm capillaries to fluid is unchanged by anoxia. However, the technique employed did not give them any information on the concentration of the protein in the filtrate and their report is in abstract form only. Another study is that by Stead and Warren (8) who have estimated the protein content of the edema fluid in 2 emphysematous patients whose arterial oxygen saturation was $\mathbf{5 0}$ to 60 per cent. They found no significant change from the normal figure of 0.25 gram per cent or less and concluded that this degree of chronic anoxia had not increased the permeability of the capillaries of the limbs. In an earlier report (9) the authors found no significant change in fluid or protein loss from the capillaries of the forearm when under the influence of acute anoxia. ${ }^{2}$ The following paper confirms these results and extends them to an estimation of the approximate oxygen tension at which a significant increase in protein filtration from the capillary bed occurs.

\footnotetext{
2 A systematic error which does not however invalidate the conclusions drawn has been detected in the calculation of the protein data presented in this report to the CAM of the OSRD and summarized in the Fed. Proc., 1946, 5, 44. The corrected figures for the calculated protein in the filtrate are 1.5 grams \pm 1.5 grams per cent when anoxic and 1.2 grams \pm 0.5 gram per cent when at sea level.
} 


\section{METHOD OF APPROACH}

The best measure of the permeability of the capillary wall would be a direct determination of the concentration of protein in the capillary filtrate (10). A significant increase in this concentration over the normal near zero ( 0.2 to 0.3 gram per cent) values found in the limb may be regarded as evidence of a change in the permeability of the wall $(1,8)$. Failing a direct determination an estimate of this measure was made by Landis et al (11) in their experiments, using various degrees of venous congestion supplied by the blood pressure cuff. The congestion cuff causes a marked slowing of blood flow without stopping it when the venous pressure imposed by it ( 60 or $80 \mathrm{~mm} . \mathrm{Hg}$ ) is less than the arterial blood pressure. The increased filtration pressure of the slowly flowing blood results in a loss of fluid into the tissues. Comparison of the hematocrit values shown by the blood in the median antecubital vein of the congested arm with that in the uncongested control arm permits an estimation of the fluid loss in $\mathrm{ml}$. per $100 \mathrm{ml}$. of the blood flowing through the congested arm. These investigators have devised a formula by which they can calculate the percentage of protein in the capillary filtrate from observations on the relative changes in hematocrit values and plasma protein levels in the blood from the control and congested arms. In such studies on the human arm, they have observed a calculated protein in the capillary filtrate at a congestion pressure of $80 \mathrm{~mm}$. $\mathrm{Hg}$ of approximately 1.5 grams per cent. This procedure produces the double effect of an increase of the hydrostatic pressure in the capillaries and an ischemic anoxia due to slowing of the blood flow through the vessels. It has been pointed out (11) that if it were possible to be sure that the high pressure in the congested capillary bed was not directly responsible for this abnormally high content of protein in the filtrate, then the experiment would provide evidence of the effect of ischemic anoxia on capillary permeability. Kunkel, Stead and Weiss (12), and more recently Allen et al (13) have shown that adrenalin injections will lead to a marked increase in the amount of blood flowing through a limb. If this increase in blood flow is enough to effectively eliminate the ischemic anoxia resulting from a congestive cuff then it should be possible to eliminate the protein loss in a congested arm by increasing the blood flow through it by the use of adrenalin. If the protein loss is eliminated in spite of the use of cuff pressures of $80 \mathrm{~mm}$. $\mathrm{Hg}$ then it can be assumed that such pressures have little effect on the permeability of the blood vessels. Another method of dissociating the effects of pressure from those of anoxia would be to decrease the venous oxygen tension while keeping the capillary pressure constant. This could be accomplished by exposing the subject to a lowered alveolar oxygen tension at a cuff pressure at which the protein in the filtrate was at the upper limit of the normal values. Reduction of the arterial oxygen saturation to 60 to 70 per cent would cause a considerable fall in the mean capillary oxygen tension. This fall should increase the protein in the capillary filtrate if permeability is significantly affected by changes in oxygen tension. Since the oxygen tension is lowest at the venous end of the capillary, the oxygen content of the venous blood should be a measure of the oxygen tension in that part of the capillary bed which is exposed to the most severe anoxia. If the content of protein in the filtrate is a measure of the permeability of the capillary wall and if this permeability is affected by the oxgen tension, then it should be possible to demonstrate a correlation between the oxygen content of the venous blood from the congested arm and the concentration of protein in the capillary filtrate.

\section{METHODS}

The subjects employed were chosen for their familiarity with experimental procedures and the majority of the tests were performed on only 3 persons. These were in good health and of an active habitus. The 2 subjects employed for the altitude studies showed no gross vasomotor disturbances with acute anoxic anoxia. There was no significant change in blood pressure, pulse or respiration rate with reduction of the arterial oxygen saturation to values of the order of 60 per cent for periods of 30 minutes. It was hoped that by employing repeated tests on a few well-trained subjects it would be possible to decrease the inherent differences between various subjects and the variations due to fluctuations of subject response.

Adrenalin hypertension was obtained by the intramuscular administration to the recumbent subjects of $6 / 10 \mathrm{ml}$. of $1 / 500$ adrenalin in peanut oil followed in 15 minutes by $1 / 10 \mathrm{ml}$. doses of $1 / 1000$ adrenalin subcutane- 
ously in sufficient number to maintain the blood pressure 20 to $40 \mathrm{~mm}$. $\mathrm{Hg}$ above the normal resting level for the subject. In the subjects employed this meant that the systolic blood pressure was maintained at 140 to $160 \mathrm{~mm}$. $\mathrm{Hg}$ for the 30 minutes of $80 \mathrm{~mm}$. $\mathrm{Hg}$ cuff application.

During the altitude tests each subject rested for 30 minutes before putting on the cuff at $60 \mathrm{~mm}$. $\mathrm{Hg}$ for 30 minutes. The temperature of the chamber in which the tests were conducted was uniform. However, no readings of skin temperature were made and it is thought that some of the variations in the results noted may have been due to minor changes in the condition of the skin and deep circulation from day to day as the tests progressed. The same arm was always used for congestion in order to decrease experimental variations.

Bloods were collected with $0.1 \mathrm{ml}$. of liquid heparin in $10-\mathrm{ml}$. syringes and immediately set up in duplicate in Wintrobe hematocrit tubes. Duplicate hemoglobins were estimated using the acid hematin technique. R.B.C. volume was obtained by correcting the hematocrit readings by a factor of 8.5 per cent for fluid trapped between the cells (14). Plasma protein concentrations were determined in duplicate using the falling drop technique. Venous oxygen content and saturations together with venous carbon dioxide contents were determined in duplicate by Van Slyke blood gas analysis in a number of the tests using $60 \mathrm{~mm}$. $\mathrm{Hg}$ congestion and anoxia and in all those using $80 \mathrm{~mm}$. $\mathrm{Hg}$ congestion with adrenalin hypertension.

Anoxia involving 55 to 65 per cent saturation of the arterial blood was obtained by ascent in a decompression chamber to a simulated altitude of 19,000 to $20,000 \mathrm{ft}$. The subjects were relaxed and dozed in a recumbent posture on a couch. Respiratory rate, blood pressure and pulse were checked every 5 minutes and the oxygen saturation followed throughout by a Millikan compensated oximeter. Contamination of the altitude chamber atmosphere by oxygen was avoided by using an oxygen mask with an exhalation valve which was connected to a tube venting directly into the chamber exhaust. The oxygen saturation, rarely higher than 65 per cent, was maintained at 60 per cent and frequently fell to 55 per cent.

\section{Calculations}

The equations used to determine the per cent protein in the filtrate were those developed by Landis et al (10). As they have pointed out $(10,11)$ these equations become less accurate with lower degrees of fluid and protein loss. In order to assess the variability introduced by these calculations of protein in the filtrate, the standard errors of the hematocrit and protein readings were determined. These were found by making repeated measurements of the same sample. They were \pm 0.2 per cent for the hematocrits and \pm 0.06 gram per cent for the plasma proteins. These values were inserted into the equations and the maximum positive and negative deviations were calculated for each set of experimental data. In Figure 1 such values obtained for each experi- ment have been plotted against the product of the hematocrit and protein differences, yielding a parameter which indicates in part at least the variability to be anticipated in the protein in the filtrate. If the product $\left(\mathrm{Ht}_{2}-\mathrm{Ht}_{1}\right)$ $\left(\mathrm{Pr}_{2}-\mathrm{Pr}_{1}\right)$ is small, a condition which would be associated either with a low fluid loss and usually small protein leakage or both, then the variability is great. High values show an increased accuracy. Inspection of Figure 1 also reveals a negative bias which is largest at the lowest values of protein change and fluid loss.

In a considerable proportion of the experiments the calculations yield negative values for protein concentration in the filtrate. Such negative values might result from a failure to take account of unrecognised physiological variables. Alternatively, in view of the large random error and more especially of the negative bias introduced by the equation, the values obtained could be the result of the mathematical skewing of the formula with consequent negative bias noted above.

\section{RESULTS}

1. Adrenalin hypertension. In Table I are presented the results of 8 cuff experiments on 3

TABLE I

Fluid loss and per cent protein in filtrate with $80 \mathrm{~mm} . \mathrm{Hg}$ congestion (controls)

\begin{tabular}{|c|c|c|c|c|c|c|}
\hline Subject & $\underset{\text { atocrit }}{\text { Hem- }}$ & $\begin{array}{l}\text { Fluid } \\
\text { loss } \\
\text { (hem- } \\
\text { atocrit) }\end{array}$ & $\begin{array}{c}\text { Fluid } \\
\text { loss } \\
\text { (hemo- } \\
\text { globin) }\end{array}$ & $\begin{array}{l}\text { Pro- } \\
\text { tein }\end{array}$ & $\begin{array}{l}\text { Protein } \\
\text { in } \\
\text { filtrate }\end{array}$ & $\begin{array}{l}\text { Satura- } \\
\text { tion of } \\
\text { venous } \\
\text { blood }\end{array}$ \\
\hline $5 c$ & $\begin{array}{l}43.4 \\
45.8\end{array}$ & $\begin{array}{c}\text { ml. per } \\
5.6\end{array}$ & $\begin{array}{r}00 \mathrm{ml} . \\
\quad 3.9\end{array}$ & $\begin{array}{l}\text { grams } \\
6.55 \\
7.10\end{array}$ & $\begin{array}{r}\text { per } \\
+1.5\end{array}$ & ent \\
\hline $5 d$ & $\begin{array}{l}41.9 \\
46.9\end{array}$ & 10.9 & 8.6 & $\begin{array}{l}6.19 \\
7.37\end{array}$ & +1.0 & 21.6 \\
\hline $5 e$ & $\begin{array}{l}40.7 \\
46.1\end{array}$ & 11.7 & 10.7 & $\begin{array}{l}5.76 \\
6.93\end{array}$ & +1.0 & 21.3 \\
\hline $7 q$ & $\begin{array}{l}41.3 \\
47.2\end{array}$ & 12.6 & 18.2 & $\begin{array}{l}6.76 \\
7.79\end{array}$ & +3.0 & 18.9 \\
\hline $7 r$ & $\begin{array}{l}42.8 \\
52.7\end{array}$ & 18.9 & 19.1 & $\begin{array}{l}6.11 \\
8.88\end{array}$ & +0.5 & 19.1 \\
\hline $7 \mathrm{~s}$ & $\begin{array}{l}43.0 \\
52.6\end{array}$ & 18.3 & 17.5 & $\begin{array}{l}5.90 \\
8.66\end{array}$ & +0.1 & 15.6 \\
\hline $6 j$ & $\begin{array}{l}39.5 \\
43.5\end{array}$ & 9.4 & 6.6 & $\begin{array}{l}5.97 \\
7.27\end{array}$ & -1.1 & 18.2 \\
\hline $6 \mathrm{k}$ & $\begin{array}{l}39.6 \\
49.6\end{array}$ & 20.1 & 17.0 & $\begin{array}{l}6.14 \\
7.82\end{array}$ & +2.8 & 16.9 \\
\hline 61 & $\begin{array}{l}41.0 \\
47.2\end{array}$ & 13.2 & 13.9 & $\begin{array}{l}5.80 \\
7.92\end{array}$ & -1.6 & 12.1 \\
\hline \multicolumn{2}{|c|}{$\begin{array}{l}\text { Average } \\
\text { Standard devia- } \\
\text { tion of mean }\end{array}$} & $\begin{array}{r}13.4 \\
\pm 1.7\end{array}$ & $\begin{array}{r}12.8 \\
\pm 1.8\end{array}$ & & $\begin{array}{l}+0.8 \\
\pm 0.5\end{array}$ & 18.0 \\
\hline
\end{tabular}


subjects using a cuff at $80 \mathrm{~mm}$. $\mathrm{Hg}$ for $30 \mathrm{~min}$ utes. There is fair agreement between the mean values for the fluid loss as calculated from the changes in the hematocrit, $13.4 \pm 1.7 \mathrm{ml}$. per $100 \mathrm{ml}$., and those calculated from the hemoglobin values, i.e., $12.8 \pm 1.8 \mathrm{ml}$. per $100 \mathrm{ml}$. This suggests that no significant changes in cell volume occur as a result of the stasis induced by the cuff experiment, for such changes would affect only the hematocrit values (10). The marked individual variations from experiment to experiment may be in part attributed to changes in rate of forearm blood flow due to differences in temperature, activity and other variables. Attempts to obtain more reliable figures by using an indwelling needle in the radial artery (15) as a source of the control blood led to no improvement. However, it is of interest that in their original series of 5 experiments using $80 \mathrm{~mm}$. $\mathrm{Hg}$ cuff pressure, Landis, et al obtained a mean fluid loss figure of $15.0 \mathrm{ml}$. per $100 \mathrm{ml}$. This compares favorably with the above values.

In Table II are seen the data obtained from

TABLE II

Fluid loss and per cent protein in filtrate with $80 \mathrm{~mm} . \mathrm{Hg}$ congestion (adrenalin hypertension)

\begin{tabular}{|c|c|c|c|c|c|c|}
\hline Subject & $\begin{array}{l}\text { Hem- } \\
\text { atocrit }\end{array}$ & $\begin{array}{c}\text { Fluid } \\
\text { loss } \\
\text { (hem- } \\
\text { atocrit) }\end{array}$ & $\begin{array}{c}\text { Fluid } \\
\text { loss } \\
\text { (hemp- } \\
\text { globin) }\end{array}$ & $\begin{array}{l}\text { Pro- } \\
\text { tein }\end{array}$ & $\begin{array}{l}\text { Protein } \\
\text { in } \\
\text { filtrate }\end{array}$ & $\begin{array}{l}\text { Satura- } \\
\text { tion of } \\
\text { venous } \\
\text { blood }\end{array}$ \\
\hline $5 f$ & $\begin{array}{l}40.1 \\
42.1\end{array}$ & $\begin{array}{c}\text { ml. per } \\
4.9\end{array}$ & $\begin{array}{r}100 \mathrm{ml} . \\
3.9\end{array}$ & $\begin{array}{c}\text { grams } \\
5.42 \\
6.17\end{array}$ & $\begin{array}{r}\text { per } \\
-3.0\end{array}$ & 24.3 \\
\hline $5 g$ & $\begin{array}{l}40.0 \\
44.0\end{array}$ & 9.2 & 10.4 & $\begin{array}{l}5.97 \\
7.07\end{array}$ & -0.1 & 27.8 \\
\hline $7 t$ & $\begin{array}{l}44.2 \\
47.4\end{array}$ & 6.8 & 4.8 & $\begin{array}{l}6.17 \\
7.24\end{array}$ & -1.5 & 42.3 \\
\hline $7 u$ & $\begin{array}{l}44.2 \\
48.3\end{array}$ & 8.5 & 7.0 & $\begin{array}{l}6.35 \\
7.58\end{array}$ & -0.5 & 35.4 \\
\hline $7 v$ & $\begin{array}{l}44.8 \\
46.5\end{array}$ & 3.6 & 4.9 & $\begin{array}{l}6.52 \\
7.03\end{array}$ & -0.8 & 51.9 \\
\hline $6 \mathrm{~m}$ & $\begin{array}{l}42.8 \\
45.2\end{array}$ & 5.1 & 5.2 & $\begin{array}{l}6.48 \\
7.03\end{array}$ & +0.9 & 19.5 \\
\hline $6 n$ & $\begin{array}{l}43.5 \\
47.2\end{array}$ & 8.1 & 7.9 & $\begin{array}{l}6.93 \\
8.23\end{array}$ & -0.8 & 14.3 \\
\hline 60 & $\begin{array}{l}42.5 \\
46.2\end{array}$ & 7.9 & 8.9 & $\begin{array}{l}5.93 \\
7.27\end{array}$ & -2.5 & 28.4 \\
\hline \multicolumn{2}{|c|}{$\begin{array}{l}\text { Average } \\
\text { Standard devia- } \\
\text { tion of mean }\end{array}$} & $\begin{array}{r}6.0 \\
\pm 0.6\end{array}$ & $\begin{array}{r}6.6 \\
\pm 0.8\end{array}$ & & $\begin{array}{l}-1.0 \\
\pm 0.3\end{array}$ & 30.5 \\
\hline
\end{tabular}

the same number of experiments on the same 3 subjects performed in the same way except that a hypertension of 140 to $160 \mathrm{~mm}$. $\mathrm{Hg}$ was maintained throughout the $1 / 2$-hour period of cuff application. The fluid loss figures show good concordance between the hemoglobin and hematocrit values. The values of $6.0 \pm 0.6$ and $6.6 \pm 0.8$ ml. per $100 \mathrm{ml}$., respectively, are almost exactly $1 / 2$ those obtained for the normal controls. This is interesting in view of the observation by Allen et al (13) that adrenalin administration can double blood flow through the uncongested arm. For if the blood flow rate were doubled and other factors such as tissue pressure remained relatively unchanged then the fluid loss per $100 \mathrm{ml}$. blood should be decreased in the same proportion.

It might be expected that the $\mathrm{A}-\mathrm{V} \mathrm{O}_{2}$ difference would be greatly decreased if such a change in flow rate had occurred. In practice the mean venous oxygen saturation rose from 18.0 per cent to 30.5 per cent. It is of interest that numbness, tingling and eventual loss of sensation to light touch developed in the congested arms in the controls. Such symptoms never occurred at 80 $\mathrm{mm}$. $\mathrm{Hg}$ cuff pressure in the cases with adrenalin hypertension. This suggests that the blood flow under these conditions is adequate to maintain normal metabolism but that the reduced flow in the absence of hypertension is insufficient to do so. It may be noted that Griffith, et al (16) point out that it is probable that adrenalin has no significant effect on tissue oxygen utilization. Therefore the rise in oxygen saturation following its use is probably not due to a decrease in tissue metabolism.

The change in the average protein percentage in the filtrate from $+0.8 \pm 0.5$ gram per cent to a mean value of $-1.0 \pm 0.3$ grams per cent as a result of the use of adrenalin is significant. It is not probable that the percentage of protein in the filtrate would change with changes in the rate of flow of the plasma past the filtering area. It would seem likely that the increase in mean venous oxygen saturation has had some part to play in the decrease in protein in the filtrate. The negative mean value for the protein figures can be explained by the bias of the expression for protein in the filtrate to negative values by the random errors of sampling and estimation. As has been 


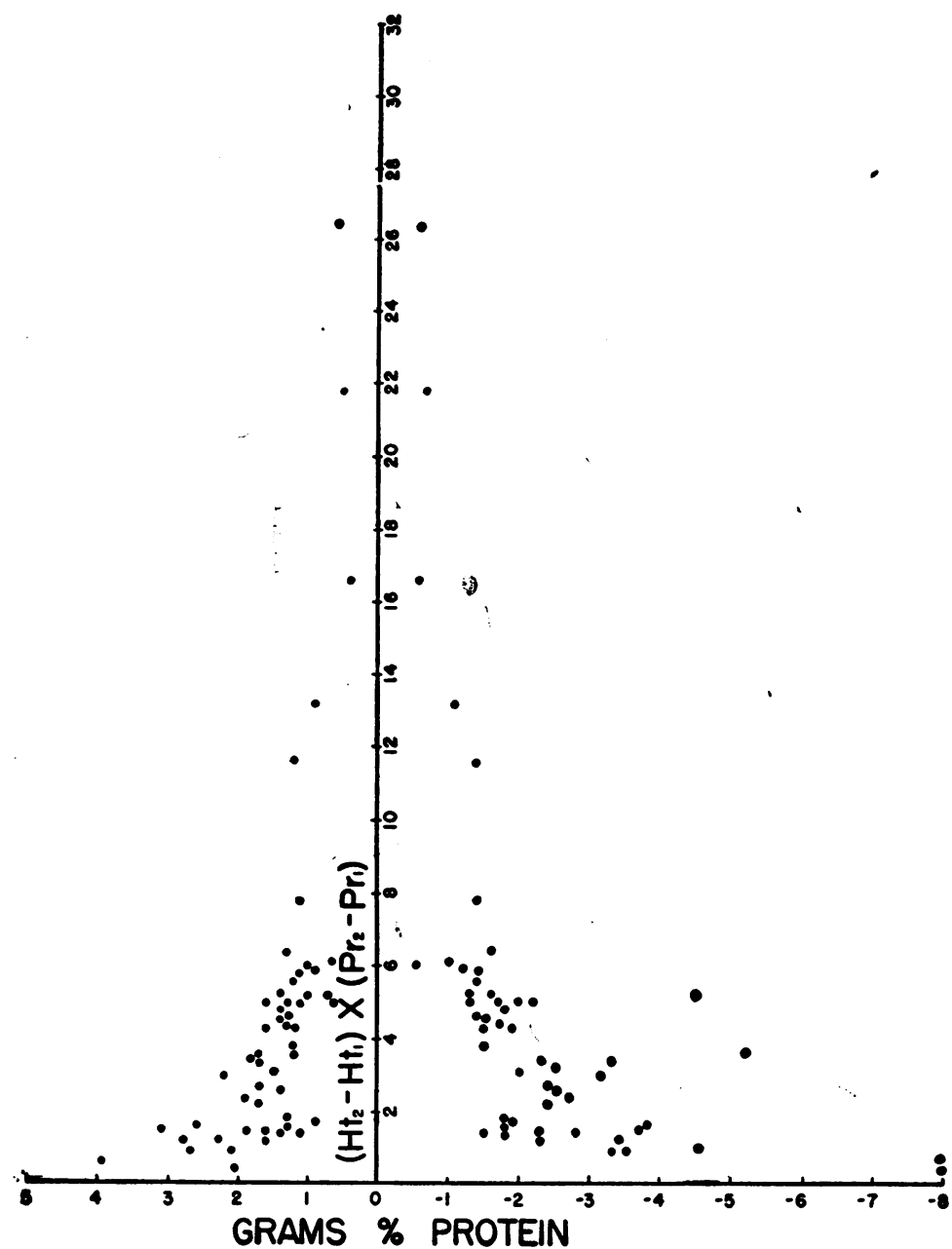

Fig. 1. Deviation in Grams Per Cent Protein of the Protein in the Filtrate Estimations Plotted against the Product of the Changes in the Hematocrit $\left(\mathrm{HT}_{2}-\mathrm{HT}_{1}\right.$ ) and the Protein Values $\left(\mathrm{PR}_{2}-\mathrm{P}_{\mathrm{R}_{1}}\right)$

pointed out under calculations (Figure 1) this error is greater in the case of the adrenalin experiments in which the fluid loss is small than in those where these changes are larger, as in the control experiments. It is not certain, however, whether there may not also be some undetermined variable which may account in part for the high negative values found in the adrenalin experiments.

The object of the adrenalin tests was to decrease the ischemic anoxia while keeping the capillary pressure constant. Since the protein in the filtrate decreased under these circumstances the possibility that the high intracapillary pressure was responsible for the increased filtration of protein in the $80 \mathrm{~mm}$. $\mathrm{Hg}$ cuff without adrenalin can be considered small. This leaves ischemic anoxia as the most probable factor responsible for the permeability changes.

2. Anoxia. In Tables III and IV are presented a series of 23 control, sea level, $60 \mathrm{~mm}$. $\mathrm{Hg}$ cuffs on 7 subjects, and 12 altitude experiments using 2 subjects. The mean sea level fluid loss of $7.6 \mathrm{ml}$. per $100 \mathrm{ml}$. $\pm 0.5 \mathrm{ml}$., as calculated from the hematocrit values, was again close enough to that calculated from the hemoglobins 
TABLE III

Fluid loss and per cent protein in filtrate with $60 \mathrm{~mm} . \mathrm{Hg}$ congestion (controls)

\begin{tabular}{|c|c|c|c|c|c|c|}
\hline Subject & $\begin{array}{l}\text { Hem- } \\
\text { atocrit }\end{array}$ & $\begin{array}{c}\text { Fluid } \\
\text { loss } \\
\text { (hem- } \\
\text { atocrit) }\end{array}$ & $\begin{array}{l}\text { Fluid } \\
\text { bss } \\
\text { (hemo- } \\
\text { globin) }\end{array}$ & Protein & $\begin{array}{c}\text { Protein } \\
\text { in } \\
\text { filtrate }\end{array}$ & $\begin{array}{l}\text { Satura- } \\
\text { tion of } \\
\text { venous } \\
\text { blood }\end{array}$ \\
\hline $\begin{array}{l}1 \mathrm{a} \\
1 \mathrm{~b} \\
1 \mathrm{c} \\
2 \mathrm{a} \\
2 \mathrm{~b} \\
3 \mathrm{a} \\
3 \mathrm{~b} \\
4 \mathrm{a} \\
5 \mathrm{a} \\
5 \mathrm{~b} \\
6 \mathrm{a} \\
6 \mathrm{~b} \\
6 \mathrm{c} \\
7 \mathrm{a} \\
7 \mathrm{~b} \\
7 \mathrm{c} \\
7 \mathrm{~d} \\
7 \mathrm{e} \\
7 \mathrm{f} \\
7 \mathrm{~g} \\
7 \mathrm{~h} \\
7 \mathrm{i} \\
6 \mathrm{~d}\end{array}$ & $\begin{array}{l}40.4 / 43.2 \\
41.4 / 43.8 \\
40.7 / 42.5 \\
38.6 / 42.4 \\
39.3 / 43.0 \\
38.3 / 41.2 \\
41.7 / 43.4 \\
43.0 / 45.7 \\
42.8 / 45.9 \\
41.0 / 43.0 \\
41.5 / 47.1 \\
40.9 / 43.6 \\
41.2 / 45.7 \\
42.5 / 46.7 \\
42.1 / 47.0 \\
44.2 / 48.2 \\
46.2 / 49.8 \\
46.0 / 48.6 \\
41.5 / 44.7 \\
42.4 / 47.1 \\
41.4 / 46.3 \\
42.5 / 47.1 \\
39.5 / 42.6\end{array}$ & $\begin{array}{c}\text { ml. per } \\
5.9 \\
4.5 \\
4.3 \\
9.1 \\
8.7 \\
7.1 \\
3.6 \\
5.8 \\
6.8 \\
4.7 \\
12.0 \\
6.1 \\
10.0 \\
8.8 \\
10.5 \\
8.4 \\
7.3 \\
5.3 \\
7.4 \\
10.1 \\
10.7 \\
9.7 \\
7.3\end{array}$ & $\begin{array}{r}100 \mathrm{ml} . \\
8.5 \\
5.1 \\
1.5 \\
6.7 \\
7.4 \\
4.0 \\
3.0 \\
\\
2.0 \\
6.3 \\
12.1 \\
9.6 \\
9.4 \\
13.9 \\
12.4 \\
3.1 \\
\\
5.1 \\
6.9 \\
20.3 \\
12.6 \\
13.2 \\
9.9\end{array}$ & \begin{tabular}{|c|} 
grams \\
$7.05 / 8.10$ \\
$7.30 / 8.03$ \\
$6.88 / 7.23$ \\
$6.94 / 8.10$ \\
$6.68 / 7.75$ \\
$6.50 / 7.03$ \\
$6.90 / 7.30$ \\
$6.46 / 7.28$ \\
$6.04 / 6.79$ \\
$5.52 / 6.11$ \\
$6.48 / 7.31$ \\
$6.17 / 6.86$ \\
$6.04 / 6.83$ \\
$6.27 / 7.28$ \\
$6.53 / 7.75$ \\
$6.45 / 7.61$ \\
$6.14 / 7.34$ \\
$7.00 / 7.51$ \\
$6.07 / 7.03$ \\
$6.55 / 7.65$ \\
$5.83 / 7.44$ \\
$5.52 / 6.79$ \\
$6.14 / 6.72$
\end{tabular} & $\begin{array}{r}\text { per } \\
-2.5 \\
-1.5 \\
+2.5 \\
+0.3 \\
+0.3 \\
+2.4 \\
+0.8 \\
-0.7 \\
+0.5 \\
-1.3 \\
+3.3 \\
+0.2 \\
+2.2 \\
+0.6 \\
+1.0 \\
-0.1 \\
-1.5 \\
+2.3 \\
-0.6 \\
+1.4 \\
-1.4 \\
-0.7 \\
+1.9\end{array}$ & $\begin{array}{l}28.7 \\
33.5 \\
13.3 \\
17.2 \\
23.0\end{array}$ \\
\hline \multicolumn{2}{|c|}{$\begin{array}{l}\text { Average } \\
\text { Standard devia- } \\
\text { tion of mean }\end{array}$} & $\begin{array}{r}7.6 \\
\pm 0.5\end{array}$ & $\begin{array}{r}8.2 \\
\pm 1.1\end{array}$ & & $\begin{array}{l}+0.4 \\
\pm 0.3\end{array}$ & 26.4 \\
\hline
\end{tabular}

of $8.2 \mathrm{ml}$. per $100 \mathrm{ml}$. $\pm 1.1 \mathrm{ml}$. to suggest that there is no significant change in red cell volume during the stasis induced by the cuff.

The mean venous oxygen saturation during the altitude experiments was 26.4 per cent. The arterial oxygen saturation was maintained at 55 to 65 per cent throughout the period of cuff application. The oxygen tension along the entire capillary was therefore much less than its normal value. On the other hand, in the subjects employed, repeated checks of systolic blood pressure during the course of the cuff application at altitude showed no significant change. The absence of a significant change in the mean fluid loss when using anoxia $(7.9 \mathrm{ml}$. per $100 \mathrm{ml}$. at sea level and $6.3 \mathrm{ml}$. per $100 \mathrm{ml}$. at altitude) contrasts with the marked change found in the experiments with adrenalin. It suggests that the pressure in the capillaries and the rate of blood flow through the forearm were not significantly affected during these latter tests. The changes found in the percentage of protein in the filtrate can therefore be attributed to the reduction in oxygen tension of the blood in the vessels. The difference between the mean value of $1.2 \pm 0.4$ grams per cent obtained during the tests at altitude when contrasted with that of $0.4 \pm 0.3$ gram per cent for the controls, represents a definite increase in protein in the filtrate as a result of the change in venous oxygen saturation from the mean of 26.4 per cent at sea level to 11.4 per cent at altitude.

In Table $\mathrm{V}$ the evidence obtained from the 2 sets of experiments is summarized. When the data from the altitude work are considered in conjunction with the evidence obtained in the adrenalin studies a picture is obtained which suggests that anoxia has some effect upon capillary

TABLE IV

Fluid loss and per cent protein in filtrate with $60 \mathrm{~mm} . \mathrm{Hg}$ congestion (arterial saturation 55 to 65 per cent)

\begin{tabular}{|c|c|c|c|c|c|c|}
\hline Subject & $\begin{array}{l}\text { Hem- } \\
\text { atocrit }\end{array}$ & $\begin{array}{c}\text { Fluid } \\
\text { loss } \\
\text { (hem- } \\
\text { atocrit) }\end{array}$ & $\begin{array}{c}\text { Fluid } \\
\text { loss } \\
\text { (hemo- } \\
\text { globin) }\end{array}$ & $\begin{array}{l}\text { Pro- } \\
\text { tein }\end{array}$ & $\begin{array}{l}\text { Protein } \\
\text { in } \\
\text { filtrate }\end{array}$ & $\begin{array}{l}\text { Satura- } \\
\text { tion of } \\
\text { venous } \\
\text { blood }\end{array}$ \\
\hline $7 j$ & $\begin{array}{l}47.2 \\
49.4\end{array}$ & $\begin{array}{c}\text { ml. per } \\
5.6\end{array}$ & $100 \mathrm{ml}$. & $\begin{array}{c}\text { grams } \\
6.83 \\
7.41\end{array}$ & $\begin{array}{r}\text { per } \\
+1.9\end{array}$ & ent \\
\hline $7 \mathrm{k}$ & $\begin{array}{l}48.8 \\
51.7\end{array}$ & 5.7 & 6.3 & $\begin{array}{l}6.96 \\
7.75\end{array}$ & +0.7 & \\
\hline 71 & $\begin{array}{l}44.2 \\
48.6\end{array}$ & 9.2 & 6.4 & $\begin{array}{l}6.79 \\
8.06\end{array}$ & +0.4 & \\
\hline $7 \mathrm{~m}$ & $\begin{array}{l}43.6 \\
47.6\end{array}$ & 8.3 & 11.0 & $\begin{array}{l}7.34 \\
8.30\end{array}$ & +1.8 & \\
\hline $7 n$ & $\begin{array}{l}43.8 \\
46.8\end{array}$ & 6.5 & 8.1 & $\begin{array}{l}6.21 \\
6.72\end{array}$ & +2.3 & 11.7 \\
\hline 70 & $\begin{array}{l}45.7 \\
48.7\end{array}$ & 6.0 & 3.2 & $\begin{array}{l}6.04 \\
6.52\end{array}$ & +2.2 & 13.0 \\
\hline $6 e$ & $\begin{array}{l}41.4 \\
44.5\end{array}$ & 7.0 & 3.9 & $\begin{array}{l}6.41 \\
7.48\end{array}$ & -1.5 & \\
\hline $6 f$ & $\begin{array}{l}38.6 \\
41.9\end{array}$ & 7.9 & 5.4 & $\begin{array}{l}6.07 \\
6.55\end{array}$ & +2.8 & \\
\hline $6 g$ & $\begin{array}{l}42.8 \\
47.5\end{array}$ & 9.6 & 9.7 & $\begin{array}{l}5.80 \\
6.89\end{array}$ & +0.4 & 11.0 \\
\hline $6 \mathrm{~h}$ & $\begin{array}{l}42.7 \\
47.4\end{array}$ & 9.9 & 8.2 & $\begin{array}{l}6.04 \\
7.10\end{array}$ & +1.2 & 8.9 \\
\hline $7 p$ & $\begin{array}{l}44.9 \\
45.8\end{array}$ & 2.0 & 0.6 & $\begin{array}{l}7.00 \\
7.13\end{array}$ & +3.6 & 14.8 \\
\hline $6 i$ & $\begin{array}{l}41.5 \\
42.5\end{array}$ & 2.4 & 0.8 & $\begin{array}{l}5.48 \\
5.76\end{array}$ & -1.0 & 9.2 \\
\hline $\begin{array}{l}\text { Average } \\
\text { Standar } \\
\text { tion }\end{array}$ & $\begin{array}{l}\text { devia- } \\
\text { nean }\end{array}$ & $\begin{array}{r}6.7 \\
\pm 0.7\end{array}$ & $\begin{array}{r}5.8 \\
\pm 1.0\end{array}$ & & $\begin{array}{l}+1.2 \\
\pm 0.4\end{array}$ & 11.4 \\
\hline
\end{tabular}


TABLE $\mathbf{V}$

Summary of changes obtained in fluid loss and per cent protein in the filtrate when anoxia is added to a $60 \mathrm{~mm}$. $\mathrm{Hg}$ congestion and adrenalin hypertension to an $80 \mathrm{~mm}$. Hg congestion experiment

\begin{tabular}{|c|c|c|c|c|}
\hline & \multicolumn{2}{|c|}{ Values based on changes in } & \multicolumn{2}{|c|}{ - Values based on changes in } \\
\hline & Hematocrits & Hemoglobins & Hematocrits & Hemoglobins \\
\hline $\begin{array}{l}\text { Mean fluid loss } \\
\text { Standard deviation } \\
\text { Mean protein in filtrate } \\
\text { Standard deviation } \\
\text { Mean venous } \mathrm{O}_{2} \\
\text { saturation }\end{array}$ & \multicolumn{2}{|c|}{$\begin{array}{l}+0.4 \text { gram per cent } \\
\pm 0.3 \text { gram per cent } \\
26.4 \text { per cent }\end{array}$} & \multicolumn{2}{|c|}{$\begin{array}{c}7 \mathrm{ml} . \\
+1.2 \text { gram per cent } \\
+1.0 \mathrm{ml} . \\
\pm 0.4 \text { gram per cent } \\
11.4 \text { per cent }\end{array}$} \\
\hline $\begin{array}{l}\text { Mean fluid loss } \\
\text { Standard deviation } \\
\text { Mean protein in filtrate } \\
\text { Standard deviation } \\
\text { Mean venous } \mathrm{O}_{2} \\
\text { saturation }\end{array}$ & $\begin{array}{c}80 \mathrm{~mm} . \mathrm{Hg}_{\mathrm{g}} \mathrm{co} \\
13.4 \mathrm{ml} \text {. per } 100 \mathrm{ml} . \\
\pm 1.7 \mathrm{ml} . \\
+0.8 \mathrm{grar} \\
\pm 0.5 \mathrm{grar} \\
18.0 \mathrm{per}\end{array}$ & $\begin{array}{l}12.8 \mathrm{ml} . \text { per } 100 \mathrm{ml} \\
\quad \pm 1.8 \mathrm{ml} . \\
\text { per cent } \\
\text { per cent } \\
\text { ent }\end{array}$ & $\begin{array}{c}80 \mathrm{~mm} . \mathrm{Bg} \text { with ad } \\
6.0 \mathrm{ml} \text {. per } 100 \mathrm{ml} . \\
\pm 0.6 \mathrm{ml} . \\
-1.0 \mathrm{gran} \\
\pm 0.3 \mathrm{gran} \\
30.5 \text { per }\end{array}$ & $\begin{array}{l}\text { enalin ( } 9 \text { expts.) } \\
\quad \begin{array}{l}\text { ml. per } 100 \mathrm{ml} \\
\pm 0.8 \mathrm{ml}\end{array} \\
\text { per cent } \\
\text { per cent } \\
\text { ent }\end{array}$ \\
\hline
\end{tabular}

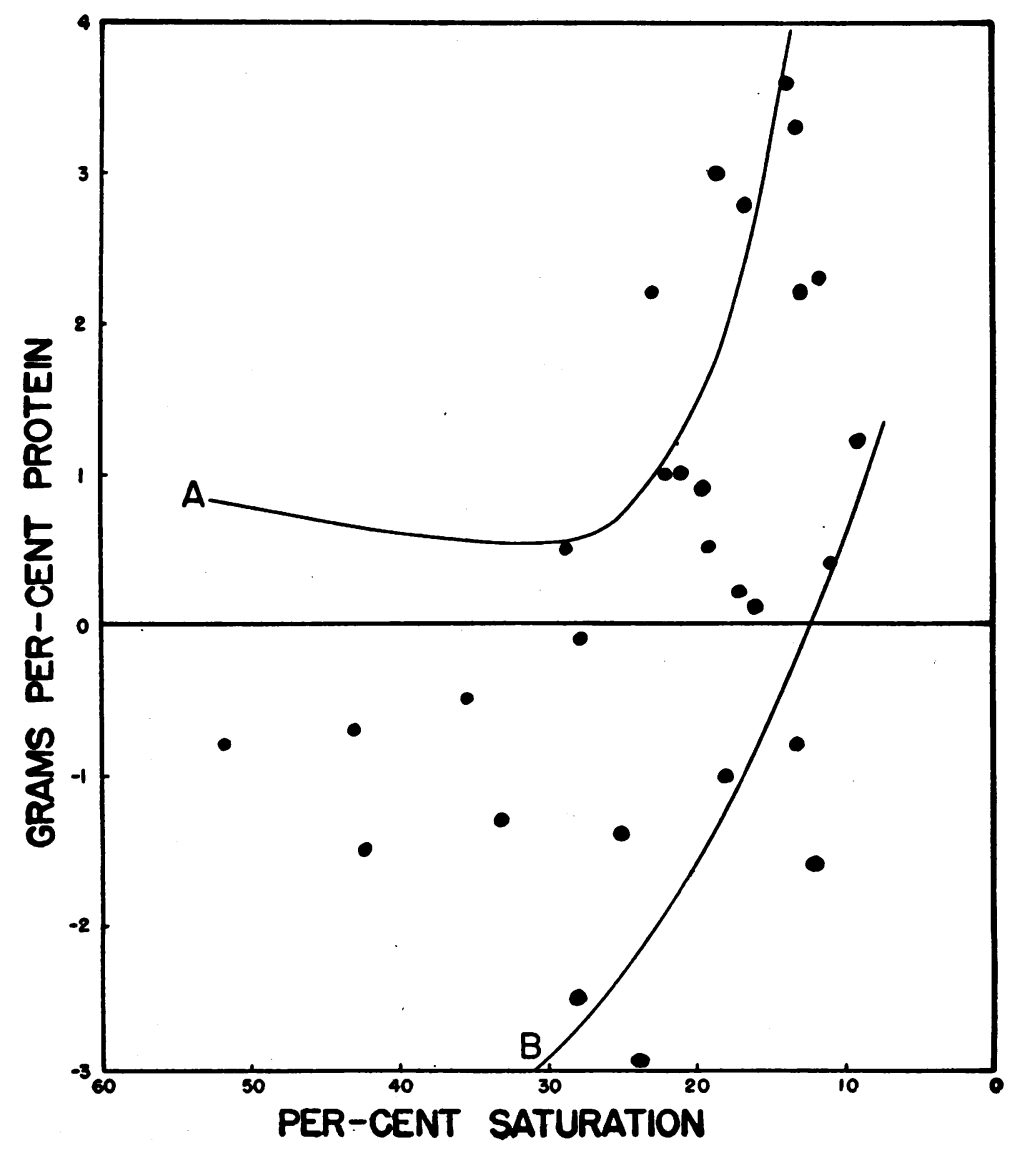

Fig. 2. Per Cent Protein in the Filtrate Plotted against Per Cent Oxygen Saturation of the Venous Blood 
permeability in the forearm when the oxygen saturation falls below the general value of 25 per cent. $^{3}$

In Figure 2 the values for protein in the filtrate are plotted against those for oxygen saturation in the venous blood. Inspection reveals a definite upward trend of these protein values at oxygen saturations of less than 25 per cent. Curve A, Figure 2, was obtained by adding to each determination of protein in the filtrate the positive deviations as calculated for Figure 1 and plotting the resulting points. Curve $\mathrm{B}$ was plotted in a similar manner using the negative deviations. They have no quantitative significance but represent an attempt to indicate qualitatively the skewing and relative accuracy of the data over the range of venous oxygen saturations considered. The convergence of these curves towards the higher values of protein in the filtrate is an expression of the lower random error at the higher values for protein and fluid loss. The marked negative bias of the error especially in the determinations with higher values of oxygen saturation probably accounts in large measure for those negative values observed. The essential feature portrayed is the increase in the protein in the filtrate with oxygen saturation values of less than 20 to 30 per cent. This is clearly shown on inspection of the data and can be confirmed by the above mathematical considerations.

\section{DISCUSSION}

- The foregoing results suggest that it is necessary for the oxygen tension in the capillary bed of the human arm to drop to values below 15 to $25 \mathrm{~mm}$. $\mathrm{Hg}$ corresponding to an oxygen saturation of 15 to 25 per cent, or an oxygen content of 4 to 6 vols. per cent in those with a normal hemoglobin content, before any significant changes in permeability to protein can be expected. However, if the oxygen tension falls below this value, there is good evidence that the anoxia is then of

${ }^{3}$ Although venous oxygen determinations were not made for all of the $60 \mathrm{~mm}$. cuff experiments ( 7 of 23 controls and 6 of 12 altitude experiments) the arterial oxygen saturation was reduced by the same amount in all cases. It is therefore assumed that the average venous oxygen saturation of those samples in which this measurement was not made would have been of the same order as the determined values. sufficient severity to increase capillary permeability even when it is of short duration. It is of interest that even during decompensation the oxygen content in blood from the antecubital vein of cardiac patients only rarely falls to such values (17). Nor are such values met in pneumonia except in moribund cases (18). In the cases of emphysema with cardiac failure described by Stead and Warren (8), in which there was no increase in protein in the edema fluid in spite of an arterial saturation of 50 to 60 per cent, the venous oxygen content was not recorded. It is possible that despite the severe anoxic anoxia the venous $\mathrm{O}_{2}$ saturation was not below the critical level of 15 to 25 per cent. One reason for making this assumption is the fact that such patients often have polycythemia and their blood can therefore yield more oxygen before reaching any particular degree of desaturation than can the blood of those with a normal hemoglobin content.

In severe anemia the reverse of the abovementioned condition occurs and subjects with hemoglobin concentration values of 20 per cent or less show very low venous oxygen saturation values of the order of 20 per cent (19). Strauss and Fox (20) have pointed out that the tendency to water retention on administration of sodium salts to those with severe anemia was not due to a low plasma protein level or to an increased venous pressure. Although endocrine factors (21) and the effect of changes in renal blood flow (22) must first be considered in assessing the cause of this water retention, it is possible that a part of the edema sometimes noted in severe anemia may be due to increased capillary permeability as a result of anemic anoxia. It is of interest in this connection to note the incidence of edema in cases of erythroblastosis foetalis occurring in utero (23). For in such cases in addition to the severe anemic anoxia present as a result of red cell destruction there is a considerable anoxic anoxia as a consequence of the incomplete oxygenation of the fetal blood by the placenta.

Aub and Cunningham (24) have shown that in irreversible traumatic shock the venous oxygen content may fall as low as 3 to 4 vols. per cent, representing saturations of the order of 15 to 20 per cent. It is possible that in this condition the venous oxygen tension may be low enough to 
result in a generalized increase in capillary permeability. This conclusion would fit with the observations of Fine and Seligman $(25,26)$. They have noted that following saline therapy in hemorrhagic shock, plasma proteins are carried out of the blood stream with the saline and that this occurs to a greater extent in irreversible than in reversible shock. These authors state their impression that "in irreversible shock the integrity of the capillaries as measured by the passage of radioactive protein may be impaired." Even in their more severe cases the venous oxygen saturation rarely fell as low as $\mathbf{5}$ vols. per cent and it would seem probable that only in the terminal phases of shock does the capillary oxygen content fall to values of 3 to 4 vols. per cent; that is, to levels where definite evidence of an increase in capillary permeability can be anticipated.

In their studies of the effects of anoxia on lymph production Maurer (5), working with the cervical lymph of dogs, and Warren and Drinker (6), with that from the lungs, both demonstrated a marked increase in lymph flow when the oxygen content in the inspired air was reduced to values of 10 per cent or less. Although they did not make direct estimations of venous oxygen tensions it is possible to interpolate figures from the data supplied by Davies (27) concerning the mean venous oxygen tension during varying degrees of anoxic anoxia. His data suggest that the oxygen saturation of the mixed venous blood in the lungs in their studies was probably not less than 35 per cent except in the cases where the oxygen percentage in the inspired air was considerably less than 10 per cent. Adrenalin secretion may be stimulated by anoxic anoxia of this degree and there is increased lymph production from the cervical lymphatics following the use of adrenalin (28). Although there was an increase in the total amount of lymph protein produced by their dogs, there was a decrease in the concentration of protein in the lymph collected during the anoxic episodes. This decrease is unexpected if the cause of the increased lymph flow is an increase in permeability of the capillary wall. If, however, the increased lymph production is due in large measure to changes in the blood flow through the capillary bed, then the fall in lymph protein concentration can be more readily explained. In those cases where the oxygen content in the inspired air was less than 10 per cent and in which the arterial oxygen saturation fell to less than 50 per cent, it is probable that the oxygen saturation of the mixed venous blood was within the critical range of 15 to 25 per cent necessary for the development of an increased capillary permeability. If our figures, determined from studies using the human forearm, also apply to the pulmonary capillary network, it is probable that in these cases anoxia played a direct part in the increased lymph flow.

Pochin (2) was led to his study of the relation of gross ischemia to edema formation by his observation of edema in a human limb, to which the circulation had been obstructed for 10 hours. It is possible to develop far higher grades of recoverable anoxia in isolated parts. of the body such as a limb, ear, or finger, than in the entire organism which includes regions of very great sensitivity to anoxia such as the brain. Consequently, it is to be anticipated that evidence of edema formation as a result of anoxia of the capillary walls would be found in cases where the arterial blood supply to a region was grossly impaired. De Takats (29) has observed the frequent occurrence of edema in conditions such as traumatic angiospasm, acute peripheral trophoneurosis and even in Buerger's disease. He emphasizes that this edema will vanish after sympathectomy or sympathetic paralysis. These procedures do not necessarily relieve any venous obstruction that may be present in such cases. This points to a relief of the anoxia of the capillary wall, resulting from the improved blood flow, as the probable cause of the improvement of the edema. Homans (30) has recently confirmed this opinion that the edema so frequently observed in arterial spasm is due to anoxia of the capillary wall. Oschner and De Bakey (31) in a discussion of the mechanism of development of edema in thrombophlebitis, conclude that it is not solely due to the increase in venous pressure as a result of the obstruction to the venous drainage from the part. They consider that reflex vasospasm of the arteries is a most important factor and that as a result of the vasospasm there is a relative anoxia of the capillary endothelium with an en- 
suing increase in permeability. If blocking the sympathetic pathways is effective in relieving arterial spasm, then the blood flow through the part increases, the oxygen saturation in the venous blood rises and at the same time the edema decreases. It would be of interest to know the oxygen saturation of blood draining from the edematous regions before and after sympathetic paralysis in such cases.

It is known that in the liver which largely depends on venous blood for nourishment, the oxygen tension in the blood in the hepatic veins may fall to very low levels. Thus Engel, Harrison, and Long (32) and also McMichael (33) note hepatic venous oxygen saturations in the cat of 3 to 30 per cent during hemorrhage. These low values were often obtained before the blood pressure had fallen significantly below its initial level. Frank, Seligman, and Fine (34) have associated the susceptibility of the liver to damage in shock with this peculiarity of the blood supply. It would be of interest to know what part anoxia of the liver capillaries might play in their known high permeability to protein (10) and whether the effects of anoxia on capillary permeability to protein differ in the different regions of the body. Finally, it may be noted that this work has been carried out with acute anoxia lasting for 30 minutes only. It is not known whether prolonging the duration of the anoxia would significantly raise the critical level of oxygen tension at which capillary damage first occurs. However, the failure of Stead and Warren (8) to observe an increase in protein in the extracellular fluid in their subjects with chronic anoxia would suggest that this does not occur.

The preceding observations indicate that anoxia commences to affect capillary permeability to the point of significant protein leakage at a very low oxygen tension. The result is that it usually requires a combination of one or more of the factors, ischemia, anoxic anoxia, anemia, or a great increase in tissue oxygen consumption, to attain a sufficiently low level. It may be concluded that in states of uncomplicated mild anoxic anoxia there is no reason to anticipate changes in the capillary permeability of the limbs. On the other hand, in conditions such as fatal asphyxia, irreversible shock, and ischemia in which the venous oxygen saturation may fall below the critical level of 15 to 25 per cent a significant increase in permeability probably occurs a few minutes after the commencement of such anoxia.

\section{SUM MARY}

1. A number of venous occlusion experiments of 30 minutes' duration were performed with and without anoxic anoxia and with and without adrenalin hypertension.

2. The calculated protein in the capillary filtrate was not increased until the local anoxia was of such a degree that the oxygen saturation in the venous blood draining from the arm was 15 to 25 per cent or less.

3. The experiments with adrenalin hypertension suggested that ischemic anoxia and not the concomitant increase in capillary pressure is. responsible for the increased amount of protein found in the filtrate resulting from the use of an arm cuff at a pressure of $80 \mathrm{~mm}$. $\mathrm{Hg}$.

4. In states of mild anoxia there is no reason to anticipate changes in the capillary permeability of the limbs. However, in asphyxia, irreversible shock, and in severe local ischemia or other states in which the venous oxygen saturation may fall below a critical level of 15 to 25 per cent, a significant increase in permeability to protein probably occurs a few minutes after the commencement of such anoxia.

\section{BIBLIOGRAPHY}

1. Landis, E. M., Micro-injection studies of capillary permeability; effect of lack of oxygen on permeability of the capillary wall to fluid and to plasma protein. Am. J. Physiol., 1928, 83, 528.

2. Pochin, E. E., Edema following ischemia in the rabbit's ear. Clin. Sci., 1939-42, 4, 341.

3. Calvin, D. B., The effect of asphyxia on plasma volume and protein concentration. Am. J. Physiol., 1941, 133, 233.

4. Hopps, H. 'C., and Lewis, J. H., Studies on capillary permeability as affected by anoxemia. Am. J. Path., 1946, 22, 656.

5. Maurer, F. W., Effects of decreased blood $\mathrm{O}_{2}$ and increased blood $\mathrm{CO}_{2}$ on flow and composition of cervical and cardiac lymph. Am. J. Physiol., 1940, 131, 331.

6. Warren, M. F., and Drinker, C. K., The flow of lymph from the lungs of the dog. Am. J. Physiol., 1942, 136, 207. 
7. McMichael, J., and Morris, K. M., Acute oxygen lack and capillary permeability in man. J. Physiol., 1936, 87, 74P.

8. Stead, E. A., and Warren, J. W., Protein content of the extracellular fluid in normal subjects after venous congestion and in patients with cardiac failure, anoxemia, and fever. J. Clin. Invest., 1944, 23, 283.

9. Henry, J. P., Klain, I., Movitt, E., and Meehan, J., On the effects of acute anoxia on the permeability of the capillaries in the human arm. CAM Report No. 497 to NRC Div. of Med. Sciences January 25, 1946. Summary Fed. Proc., 1946, 5, 44.

10. Landis, E. M., Capillary permeability and the factors affecting the composition of capillary filtrate. Ann. New York Acad. Sciences, 1946, 46, 713.

11. Landis, E. M., Jonas, L., Angevine, M., and Erb, W., The passage of fluid and protein through the human capillary wall during venous congestion. J. Clin. Invest., 1932, 11, 17.

12. Kunkel, P., Stead, E. A., and Weiss, S., Blood flow and vasomotor reactions in the hand, forearm, foot and calf in response to physical and chemical stimuli. J. Clin. Invest., 1939, 18, 225.

13. Allen, W. J., Barcroft, H., and Edholm, O. G., On the action of adrenalin on the blood vessels in human skeletal muscle. J. Physiol., 1946, 105, 255.

14. Chapin, M. A., and Ross, J. F., The determination of the true cell volume by dye dilution, by protein dilution and with radioactive iron: The error of the centrifuge hematocrit. Am. J. Physiol., 1942, 137, 447.

15. Henry, J., Greeley, P. O., Frykman, V. L., and Peterson, L., An indwelling needle for use in the radial artery. Science, 1946, 104, 299.

16. Griffith, F. R., Omachi, Akira, Lockwood, J. E., and Loomis, T. A., The effect of intravenous adrenalin on blood flow, sugar retention, lactate output and respiratory metabolism of peripheral (leg) tissues in the anesthetized cat. Am. J. Physiol., 1947, 149, 64.

17. Lundsgaard, C., Studies of oxygen in the venous blood. IV. Determinations on five patients with incompensated circulatory disturbances. J. Exper. Med., 1918, 27, 219.

18. Stadie, W. C., The oxygen of the arterial and venous blood in pneumonia and its relation to cyanosis. J. Exper. Med., 1919, 30, 215.

19. Sharpey-Schafer, E. P., Transfusion and the anemic heart. Lancet, 1945, 2, 296.

20. Strauss, M., and Fox, H. J., Anemia and water retention. Am. J. M. Sc., 1940, 200, 454.
21. Futcher, P., and Schroeder, H., Studies on congestive heart failure. II. Impaired renal excretion of sodium chloride. Am. J. M. Sc., 1942, 204, 52.

22. Merrill, A. J., Edema and decreased renal blood flow in patients with chronic congestive heart failure; evidence of "forward failure" as the primary cause of edema. J. Clin. Invest., 1946, 25, 389.

23. Diamond, L. K., Blackfan, K. D., and Baty, J., Erythroblastosis fetalis and its association with universal edema of the fetus, icterus gravis neonatorum and anemia of the newborn. J. Pediat., 1932, 1, 269.

24. Aub, J. C., and Cunningham, T. D., Studies in experimental traumatic shock. II. The oxygen content of the blood. Am. J. Physiol., 1920-21, 54, 408.

25. Fine, J., and Seligman, A. M., Traumatic shock. VII. A study of the problem of the "lost plasma" in hemorrhagic, tourniquet, and burn shock by the use of. radioactive iodoplasma protein. J. Clin. Invest., 1944, 23, 720.

26. Fine, J., and Seligman, A. M., Traumatic shock. IV. A study of the problem of the "lost plasma" in hemorrhagic shock by the use of radioactive plasma protein. J. Clin. Invest., 1943, 22, 285.

27. Davies, B. D., The indirect measurement of mean venous oxygen tension during anoxia. J. Clin. Invest., 1944, 23, 666.

28. Drinker, C. K., Warren, M. F., Maurer, F. W., and and McCarrell, J. D. The flow, pressure and composition of cardiac lymph. Am. J. Physiol., 1940, 130, 43.

29. de Takats, G., Reflex dystrophy of the extremities. Arch. Surg., 1937, 34, 939.

30. Homans, J., Vasomotor and other reactions to injuries and venous thrombosis. Am. J. Med. Sc., 1943, 205, 313.

31: Ochsner, A., and DeBakey, M., Thrombophlebitis : The role of vasospasm in the production of the clinical manifestations. J. A. M. A., 1940, 114, 117.

32. Engel, F. L. Harrison, H. C., and Long, C. N. H., Biochemical studies on shock. III. The role of the liver and the hepatic circulation in the metabolic changes during hemorrhagic shock in the rat and the cat. J. Exper. Med., 1944, 79, 9.

33. McMichael, J., The oxygen supply of the liver. Quart. J. Exper. Physiol., 1937, 27, 73.

34. Frank, H. A., Seligman, A. M., and Fine, J., Traumatic shock. XIII. The prevention of irreversibility in hemorrhagic shock by vivi-perfusion of the liver. J. Clin. Inveșt., 1946, 25, 22. 